\title{
ANALISIS KEPUASAN WISATAWAN MANCANEGARA TERHADAP TOURIST INFORMATION CENTRE DI LABUAN BAJO, NUSA TENGGARA TIMUR
}

\author{
Dewi Handriana N. Meo ${ }^{1}$, I Nyoman Sudiarta ${ }^{2}$, I Ketut Suwena ${ }^{3}$ \\ ${ }^{1}$ Email : dewyhandryana0404@gmail.com \\ Program Studi Industri Perjalanan Wisata, Fakultas Pariwisata, Universitas Udayana \\ ${ }^{2}$ Email : sudiarta.nyoman@yahoo.co.id \\ Program Studi Industri Perjalanan Wisata, Fakultas Pariwisata, Universitas Udayana \\ 32Email : suwenaketut@yahoo.co.id \\ Program Studi Industri Perjalanan Wisata, Fakultas Pariwisata, Universitas Udayana
}

\begin{abstract}
Tourist Information Center (TIC) is a facility that provides specific information about local areas, tourist attractions, festivals and all services related to tourism in the area. The purpose of this study was to determine how much influence the Quality of Service and Trust Affected on Foreign Tourist Satisfaction Using the Tourist Information Center in Labuan Bajo East Nusa Tenggara. Determination of samples in this study using purposive sampling method as many as 115 respondents. Data collection techniques using questionnaires, observation, interviews, documentation, and literature. The data analysis technique in this study is descriptive analysis, validity and reliability, classic assumptions, multiple regression analysis, correlation analysis, and coefficient of determination analysis using SPSS version 17.0.The results of this study indicate the effect of service quality on the satisfaction of foreign tourists using the Tourist Information Center in Labuan Bajo was stated to have a very significant effect with a tcount of 5.243>t table 2.23214. The effect of trust on satisfaction shows a significant value of 8.924> $\mathrm{t}$ table 2.23214, while for the influence of service quality and trust simultaneously on satisfaction is significant with a value of $151.617>t$ table 1.770 .
\end{abstract}

Abstrak: Tourist Information Center (TIC) merupakan fasilitas yang menyediakan informasi khusus tentang kawasan lokal, daya tarik wisata, festival, dan semua pelayanan yang berkaitan dengan kepariwisataan didaerah tersebut.Tujuan penelitian ini untuk mengetahui besarnya Pengaruh Kualitas Pelayanan dan Kepercayaan Terhadap Kepuasan Wisatawan Mancanegara Menggunakan Tourist Information Centre Di Labuan BajoNusa Tenggara Timur. Penentuan sampel dalam penelitian ini menggunakan metode purposive sampling sebanyak 115 responden. Teknik pengumpulan data menggunakan kuesioner, observasi, wawancara, dokumentasi, dan kepustakaan. Teknik analisis data dalam penelitian ini adalah analisis deskriptif, uji validitas dan reabilitas, asumsi kelasik, analisis regresi berganda, analisis korelasi, dan analisis koefisien determinasi dengan menggunakan SPSS versi 17.0. Hasil penelitian ini menunjukkan pengaruh kualitas pelayanan terhadap kepuasan wisatawan mancanegara yang menggunakan Tourist Information Centredi Labuan Bajo dinyatakan sangat berpengaruh signifikan dengan nilai thitung $5.243>$ ttabel 2.23214. Pengaruh kepercayaan terhadap kepuasan menunjukan signifikan dengan nilai thitung $8.924>$ ttabel 2.23214 , sedangkan untuk pengaruh kualitas pelayanan dan kepercayaan secara simultan terhadap kepuasan dinyatakan signifikan dengan nilai thitung $151.617>$ ttabel 1.770 .

Keywords: labuan bajo, service quality, trust, satisfaction, tourist information centre. 


\section{PENDAHULUAN}

Setiap daerah di Indonesia memiliki ciri khas potensi wisata tersendiri dan memiliki keunikan ragam budaya yang dapat menjadi daya tarik wisata, sehingga dapat menarik minat wisatawan untuk mengunjunginya. Hal tersebut menjadikan Indonesia sebagai negara yang berpotensi besar menjadi daerah tujuan wisata. Oleh sebab itu, pemerintah harus lebih menempatkan pariwisata sebagai suatu industri yang perlu dikembangkan dengan memanfaatkan potensi-potensi wisata yang ada di Indonesia. Pengembangan kepariwisataan merupakan salah satu terobosan untuk meningkatkan pendapatan daerah, negara dan sektor kepariwistaan akan disejajarkan kedudukanya dengan sektor lain dalam usaha meningkatkan pendapatan negara maka kepariwisataan dapat disebut sektor Industri pariwisata (Widodo, 2013). Contohnya adalah negara-negara yang nmenggantungkan pendapatan negaranya dari industri pariwisata adalah Hawai, Fiji, Karibia, Singapura, Thailand, Filipina dan Maladewa (Pitana 2005:3). Negara-negara tersebut telah berhasil menjadikan kawasan-kawasan pariwisata sebagai salah satu sektor yang sangat penting dan telah berhasil memikat hati para wisatawan untuk berkunjung, baik wisatawan lokal maupun mancanegara. Hal ini tidak lepas dari industri jasa dalam pariwisata yang mencakup pelayanan dalam memenuhi kebutuhan para wisatawan yang berunjung ke negara tersebut.

Pulau Flores adalah salah satu pulau yang ada di Nusa Tenggara Timur dan pariwisatanya telah mulai dikembangkan. Menurut Undang-Undang No. 10 Tahun 2009 tentang Kepariwisataan, keseluruhan kegiatan yang terkait dengan pariwisata yang bersifat multidimensi dan multidisiplin muncul sebagai wujud kebutuhan setiap orang dan Negara, serta interaksi antara wisatawan dan masyarakat setempat, sesama wisatawan, pemerintah daerah, dan pengusaha. Pulau Flores memiliki beberapa potensi wisata yang terkenal seperti: Taman Nasional Komodo, Danau Kelimutu, Batu Cermin, Kampung Bena, Taman Laut Tujuh Belas Pulau Riung dan Wae Rebo. Perkembangan pariwisata di Pulau Flores tergolong masih baru di dunia kepariwisataan, untuk itu sangat dibutuhkan dukungan dari pemerintahan dan masyarakat setempat.
Kabupaten Manggarai Barat merupakan salah satu kabupaten di Pulau Flores, Nusa Tenggara Timur. Berdasarkan UU RI No. 8 tahun 2003 Kabupaten Manggarai Barat terbentuk dengan ibukota Labuan Bajo, hasil pemekaran dari Kabupaten Manggarai. Labuan Bajo juga salah satu pintu gerbang terdekat para wisatawan yang ingin berkunjung ke Taman Nasional Komodo. Salah satu dari delapan arahan Presiden RI, Joko Widodo pada sidang kabinet tahun 2016 adalah memastikan kemajuan di lapangan pada 10 destinasi wisata nasional atau yang disebut 10 Bali Baru, dengan Labuan Bajo termasuk dalam 10 Bali Baru tersebut. Daya tarik wisata utama di kabupaten Manggarai Barat yang terkenal untuk wisatawan mancanegara maupun nusantara adalah Taman Nasional Komodo (TNK) dengan atraksi utama komodo (Varanus Komodoensis). Selain komodo sebagai daya tarik utama, juga terdapat daya tarik wisata lainnya yang dikembangkan oleh dinas pariwisata Kabupaten Manggarai Barat seperti: Goa Batu Cermin, Goa Rangko, Cuca Wulang, dan Cuca Rami. Jadi, tidak heran jika pariwisata alam menjadi aktifitas wisata andalan di kepulauan Flores, terutama di Kabupaten Manggarai Barat. Disini dapat diketahui tentang tingkat pertumbuhan kunjungan wisatawan yang datang ke daya tarik wisata Manggarai Barat dalam kurung waktu lima tahun terakhir (2013-2017) mengalami peningkatan setiap tahun. Hal ini disebabkan oleh kegiatan promosi yang dilakukan pemerintah untuk memperkenalkan daya tarik wisata di Manggarai Barat.

Tingkat kunjungan wisatawan mancanegara maupun nusantara ke daya tarik wisata Manggarai Barat pada lima tahun terakhir mengalami peningkatan setiap tahun. Hal ini disebabkan oleh kegiatan promosi yang dilakukan pemerintah untuk memperkenalkan daya tarik wisata di Manggarai Barat kepada wisatawan. Jumlah kunjungan wisatawan terendah terjadi pada tahun 2013, sedangkan jumlah kunjungan wisatawan tertinggi terjadi pada tahun 2017 dengan persentase $33,49 \%$, dan rata-rata pertumbuhan dari tahun 2013 sampai tahun 2017 adalah 21,72\%. Adanya kunjungan wisatawan yang semakin meningkat setiap tahun, karena pemerintah Kabupaten Manggarai Barat sudah mulai memperhatikan 
sarana dan prasarana untuk memenuhi kebutuhan wisatawan selama berkunjung di Manggarai Barat sehingga pariwisata Manggarai Barat dapat menjadi lebih baik. Menurut Yoeti (1992), sarana wisata dapat dibagi menjadi tiga unsur, diantaranya : (1). Sarana pokok pariwisata didalamnya termaksud travel agent, perusahaanperusahaan angkutan wisata, restoran, daya tarik wisata dan atraksi wisata. (2). Sarana pelengkap kepariwisataan menyediakan fasilitas untuk rekreasi, fungsinya tidak hanya melengkapi sarana pokok kepariwisataan, tetapi yang terpenting adalah membuat para wisatawan lebih lama tinggal pada suatu daerah tujuan wisata. (3). Sarana penunjang kepariwisataan berfungsi bukan hanya membuat para wisatawan betah pada suatu daerah tujuan wisata tetapi juga membuat para wisatawan mengeluarkan biaya untuk kebutuhan dan keinginan di tempat wisatawan kunjungi.

Industri pariwisata memiliki ciri utama yaitu pelayanan, dikarenakan masing-masing perusahaan adalah perusahaan jasa yang bekerjasama menghasilkan produk untuk memenuhi kebutuhan wisatawan (Suwena, 2010). Untuk memenuhi kebutuhan wisatawan dapat dilakukan dengan cara koordinasi. Menurut Mill (2000) koordinasi merupakan fungsi kontrol dalam bentuk komunikasi diantara perusahaan penyedia jasa wisata dan wisatawan. Salah satu fasilitas penyedia jasa yang dimiliki kabupaten Manggarai Barat dalam memberikan informasi terkait kebutuhan wisatawan adalah Tourist Information Centre (TIC). TIC merupakan fasilitas yang menyediakan informasi khusus tetang kawasan lokal, daya tarik wisata, festival dan pelayanan (Mill, 2000). Sesuai Undang-Undang No. 10 Tahun 2009 tentang kepariwisataan, Pasal 20A menyatakan setiap wisatawan berhak mendapatkan informasi yang akurat mengenai daya tarik wisata. Dengan tersedianya TIC membuat wisatawan mendapatkan jawaban yang terpercaya bagi pertanyaan yang diajukan dan memberi kesempatan untuk mengenalkan suatu produk kepada wisatawan. Akan tetapi dalam mengambil keputusan, wisatawan selalu berhati-hati. Menurut Wahab (1997) ada dua alasan penyebab calon wisatawan selalu berhati-hati dalam mengambil keputusan yaitu: takut kehilangan uang, dan khawatir ditipu.
Berdasarkan observasi dan wawancara peneliti kepada beberapa karyawan TIC di Labuan Bajo bahwa kendala yang sering dihadapi dalam memberikan informasi kepada wisatawan adalah bahasa, karena sebagian besar karyawan TIC hanya bisa berbahasa inggris seadanya, sedangkan wisatawan mancanegara yang menggunakan TIC berasal dari negara yang berbeda sehingga tidak semuanya bisa berbahasa Inggris. Pernyataan ini didukung oleh hasil observasi dan informasi dari beberapa wisatawan mancanegara yang mengatakan bahwa bahasa merupakan salah satu kendala yang mereka hadapi selama berada di Labuan Bajo dan pelayanan yang diberikan kurang memuaskan seperti ketepatan waktu ketika karyawan TIC sudah membuat janji dengan wisatawan. Hal ini menyebabkan kurangnya interaksi antara wisatawan dengan karyawan TIC. Selain itu, wisatawan juga mengeluh dikarenan karyawan TIC mengatakan bahwa pada salah satu paket wisata yang ditawarkan, wisatawan dapat melakukan snorkeling dengan aman. Namun kenyataannya, wisatawan tidak dapat melakukan snorkeling dengan nyaman karena terdapat landak laut atau yang sering disebut bulu babi pada pantai tersebut. Hal ini menyebabkan beberapa wisatawan merasa kecewa. Kepercayaan dan kepuasan wisatawan merupakan salah satu kunci keberhasilan suatu produk jasa yang ditawarkan, mengingat dari kepercayaan wisatawan, maka wisatawan akan puas dan siap menerima resiko jika menggunakan produk jasa tersebut. Pelayanan yang berkualitas akan dipandang sangat penting dalam mencapai kepercayaan dan kepuasan wisatawan. Adanya TIC di Manggarai Barat, menjadikan peneliti ingin mengetahui pengaruh kualitas palayanan dan kepercayaan terhadap kepuasan wisatawan yang menggunakan TIC di Labuan Bajo Nusa Tenggara Timur tersebut.

\section{METODE PENELITIAN}

Lokasi penelitian TIC ini berada di Jalan Soekarno Hatta daerah Kampung Ujung, Labuan Bajo, Kabupaten Manggarai Barat, Kepulauan Flores, Provinsi Nusa Tenggara Timur. Tiga variabel yang akan dibahas dalam penelitian ini yaitu variabel kualitas pelayanan yang meliputi bukti langsung, empati, daya tanggap, kehandalan dan jaminan. Sedangkan variabel yang kedua yaitu kepercayaan yang 
indikatornya meliputi trusting belief dan trusting intention. Variabel terakhir adalah kepuasan yang indikatornya meliputi kesesuaian harapan, minat berkunjung kembali dan kesediaan merekomendasi. Teknik pengumpulan data yang dipergunakan dalam penelitian ini adalah: 1. Metode observasi, yaitu teknik pengumpulan data dengan cara mempelajari perilaku manusia, proses kerja, gejala-gejala alamdan dilakukan kepada responden yang tidak terlalu besar dan dibantu dengan teknik pencatatan dan dokumentasi (Umar, 2008:51). Observasi dalam penelitian ini adalah melakukan pengamatan secara langsung untuk mendapatkan gambaran dan data yang jelas tentang permasalahan yang akan diteliti di beberapa TIC yang berada di Jl. Soekarno Hatta daerah Kampung Ujung. 2. Wawancara merupakan pertemuan dua orang untuk bertukar informasi dan ide melalui tanya jawab, sehingga dapat dikontruksikan makna dalam suatu topik tertentu (Sugiyono, 2013:145). Wawancara dalam penelitian ini dapat dilakukan dengan cara mewawancarai pihak pengelolah TIC tentang pelayanan yang diberikan karyawan TIC dan fasilitas apa saja yang tersedia untuk wisatawan. 3. Kusioner adalah sejumlah pertanyaan tertulis yang digunakan untuk memperoleh informasi dari responden dalam arti laporan tentang pribadinya (Suharsimi Arikunto, 2002:128). Pada penelitian ini penenliti akan menyebarkan 115 kuesioner kepada wisatawan mancanegara yang menggunakan empat jasa TIC. Dikarenakan dari 10 TIC yang berada di Jl.Soekarno Hatta daerah Kampung Ujung, hanya terdapat empat jasa TIC yang sudah mempunyai perijinan yang lengkap. 4. Dokumentasi yaitu teknik pengumpulan data berupa arsip-arsip atau foto-foto terkait dengan pelayanan yang diberikan olehkaryawan TIC kepada wisatawan. 5. Studi kepustakaanyakni teknik pengumpulan data dengan mengadakan penelaahan terhadap buku-buku, literatur, catatan, dan laporan yang berhubungan dengan masalah yang akan diteliti (Nazir 1988). Dalam penelitian ini teknik penentuan informan menggunakan sample purposif (purposive sampling). Menurut Narbuko (2009:116) teknik puposive sampling yaitu teknik yang berdasarkan pada ciri-ciri atau sifat-sifat yang mempunyai hubungan erat dengan ciri-ciri atau sifat-sifat yang ada dalam populasi yang sudah diketahui sebelumnya. Informan dalam penelitian ini adalah karyawan TIC dan manager TIC.

Sampel dipilih berdasarkan metode purposive sampling. Sugiyono (2016) mengatakan bahwa Metode purposive samplingmerupakan teknik penentuan sample berdasarkan pertimbangan tertentu". Dalam penelitian ini peneliti memberikan peluang atau kesempatan kepada wisatawa mancanegara yang secara kebetulan berada di lokasi penelitian dan sedang menggunakan TIC di Kabupaten Manggarai Barat. Teknik analisis data yang digunakan dalam penelitian ini yaitu analisis deskriptif kualitatif dan analisis deskriptif kuantitatif. Menurut Sudman dan Blair (dalam Istijanto 2005;87), menjelaskan bahwa analisis deskriptif kualitatif bersifat memaparkan hasil temuan secara mendalam melalui pendekatan bukan angka. Sedangkan analisis deskriptif kuantitatif yaitu data yang berisi hasil pengukuran data seperti penyebaran angket atau kuesioner dan diterjemahkan ke dalam kata-kata yang mudah dimengerti. Setelah peneliti menyebarkan kuesioner, maka pada analisis kuantitatif ini akan di uji validitas dan reabilitas, uji asumsi klasik, ananlisis regresi berganda, analisis korelasi, dan analisis koefisien determinasi.

\section{HASIL DAN PEMBAHASAN}

Kabupaten Manggarai Barat memiliki sebuah keunikan khas yang sangat mendunia yaitu Taman Nasional Komodo berada didalam wilayah administratif Manggarai Barat. Taman Nasional meliputi Pulau Komodo (33.937 ha), Pulau Rinca (19.625 ha), serta pulau-pulau kecil di sekitarnya berada didalam wilayah administratif Kabupaten Manggarai Barat. Terlebih lagi dengan semakin dikenalnya Komodo di mancanegara melalui ajang mencari tujuh keajaiban alam dunia yang baru New 7 Wonders, secara tidak langsung adalah bentuk lain sebuah promosi wisata bagi Taman Nasional Komodo di Kabupaten Manggarai Barat.

Perkembangan kepariwisataan di daerah Labuan Bajo tidak lepas dari upaya-upaya yang sedang dilakukan oleh pemerintah provinsi Nusa Tenggara Timur terutama pemerintah Kabupaten Manggarai Barat. Peran pemerintah terutama dari dinas Pariwisata provinsi maupun Kabupaten 
Manggarai Barat sangat membantu dalam mempromosikan kepariwisataan melalui program-program dan event-event di Manggarai Barat untuk meninggkatakan kunjungan wisatawan ke Labuan Bajo, Manggarai Barat. Salah satu media promosi pariwisata adalah TIC. TIC bertujuan untuk mendukung pariwisata di Indonesia dan tentunya memudahkan para wisatawan memperoleh informasi seputar pariwisata.Informasi yang diberikan kepada wisatawan tentang beberapa daya tarik wisata di Labuan Bajo kabupaten Manggarai Barat sendiri. Selain itu, TIC di Labuan Bajo juga memberikan informasi mengenai hotel, akomodasi, transportasi dan rumah makan sesuai dengan keinginan wisatawan tersebut. Selain memberikan jawaban secara langsung kepada wisatawan yang menanyakan informasi, peran Tourist Information Centre juga menyediakan brosur atau pamflet berisi gambaran besar tentang daya tarik wisata di Labuan Bajo. Sebagian besar TIC di Labuan Bajo menjual paket tour ke Taman Nasional Komodo (TNK), dikarenakan daya tarik wisata utama Labuan Bajo adalah Komodo. Berdasarkan wawancara dengan kepala seksi usaha dan jasa pariwisata Dinas Pariwisata dan Kebudayaan Kabupaten Manggarai Barat bahwa terdapat 10 TIC berada di daerah Kampung Ujung dan hanya terdapat empat TIC yang sudah memiliki surat ijin dan usaha jasa. Sedangkan enam TIC lainnya masih dalam proses perijinan dengan Dinas Pariwisata dan Kebudayaan Kabupaten Manggarai Barat. Adanya 10 TIC di daerah Kampung Ujung tersebut sebagian besar baru berdiri tahun 2015 dan 2016, sehingga hal tersebut membuat dinas pariwisata belum memiliki data kunjungan lengkap wisatawan yang sudah menggunakan TIC di daerah Kampung Ujung.

Berdasarkan hasil kuesioner, persepsi wisatawan mancanegara mengenai pengaruh kualitas pelayanan terhadap kepercayaan dan kepuasan wisatawan mancanegara yang menggunakan TIC di Labuan Bajo menjawab setuju untuk setiap pertanyaan yang diajukan oleh peneliti. Hanya ada satu jawaban sangat tidak setuju dari indikator bangunan TIC yang sangat nyaman untuk dikunjungi dan Karyawan TIC sudah memberikan perhatian khusus kepada wisatawan. Juga terdapat beberapa jawaban tidak setuju untuk setiap indikator variabel kualitas pelayanan.
Berikutnya untuk setiap indikator variabel kepercayaan rata-rata wisatawan menjawab setuju untuk setiap pertanyaan yang diajukan peneliti. Hanya terdapat beberapa jawaban tidak setuju untuk setiap indikator pada variabel kepercayaan. Untuk setiap indikator dalan variabel kepuasan, rata-rata wisatawan menjawab setuju, tetapi terdapat beberapa yang menjawab tidak setuju untuk indikator di variabel kepuasan.

Dengan menggunakan program pengolahan data SPSS, dapat diperoleh nilai koefisien regresi antara pengaruh kualitas pelayanan dan kepercayaan terhadap kepuasan wisatawan. Hasil pengujian menunjukan bahwa nilai sig. untuk pengaruh $\mathrm{X} 1$ terhadap $\mathrm{Y}$ adalah sebesar $0.000<0.05$, sedangkan thitung nilainya sebesar 5.243 dan nilai t-tabel sebesar 2.23214. Maka t-hitung 5.243>t-tabel 2.23214 dari nilai tersebut maka hipotesis pertama diterima karena terdapat pengaruh antara Kualitas Pelayanan (X1) terhadap Kepuasan (Y). Hasil pengujian menunjukan bahwa nilai sig. untuk pengaruh X2 terhadap $\mathrm{Y}$ adalah sebesar $0.000>0.05$. Sedangkan untuk t-hitung diperoleh nilai 8.924 dan nilai t-tabel 2.23214. Dapat disimpulkan bahwa thitung $8.924>2.23214$ dari hasil tersebut maka hipotesis kedua diterima dikarenakan adanya pengaruh antara Kepercayaan (X2) kepuasan (Y). Hasil pengujian menunjukan bahwa nilai sig. untuk pengaruh variabel $\mathrm{X} 1$ dan $\mathrm{X} 2$ secara simultan berpengaruh terhadap $\mathrm{Y}$ adalah sebasar $0.000<0.05$, sedangkan untuk F-hitung diperoleh nilai sebesar (151.617) dan untuk Ftabel sendiri dipereloh nilai sebesar (1.770). Hasil tersebut maka F-hitung (151.617)>Ftabel (1.770), maka dapat disimpulkan bahwa Kualitas Pelayanan (X1) dan Kepercayaan (X2) memiliki pengaruh secara simultan terhadap Kepuasan wisatawan yang menggunakan TIC di Labuan Bajo (Y). Berdasarkan perhitungan di atas dapat diketahui bahwa nilai $\mathrm{R}$ square 0.742 artinya bahwa wisatawan ditentukan oleh pengaruh kualitas pelayanan dan kepercayaan sebesar $74,2 \%$, sementara sisanya $25,8 \%$ dipengaruhi variabel kepuasan wisatawan yang menggunakan TIC di Labuan Bajo. Analisis koefisien determinasi dilakukan untuk mengetahui besar nilai variasi atau pengaruh yang diberikan oleh kualitas pelayanan dan kepercayaan terhadap kepuasan wisatawan. Berdasarkan perhitungan di atas dapat diketahui bahwa nilai $\mathrm{R}$ square 0.742 , artinya 
bahwa wisatawan ditentukan oleh pengaruh kualitas pelayanan dan kepercayaan sebesar $74,2 \%$. Sementara sisanya $25,8 \%$ dipengaruhi variabel kepuasan wisatawan yang menggunakan TIC di Labuan Bajo.

\section{SIMPULAN DAN SARAN}

Pengaruh kualitas pelayanan terhadap kepuasan wisatawan yang menggunakan TIC di Labuan Bajo memiliki berpengaruh signifikan. Pengaruh kepercayaan terhadap kepuasan juga berpengaruh signifikan Pengaruh kualitas pelayanan dan kepercayaan berpengaruh signifikan terhadap kepuasan secara simultan. Berdasarkan hasil penelitian diatas maka dapat diberikan saran, yaitu karyawan TIC perlu menguasai bahasa Inggris. Perlu ada jaminan keamanan, terutama pada produk yang ditawarkan kepada wisatawan serta karyawan TIC perlu meningkatkan kualitas pelayanan kepada wisatawan. 


\section{Kepustakaan}

Achmadi Dan Narbuko. 2009. Metodologi Penelitian. Jakarta: Bumi Aksara.

Artawan. 2014. Karakteristik Dan Persepsi Wisatawan Mancanegara Terhadap Kualitas Pelayanan Karyawan Pada Integrated Tourist Information Centre (ITIC) di Kuta Bali.

Chinomona, dkk. 2014.The Influence Of Information Quality, System Quality An Service Quality On Student's SelfEfficacy At Institusions Of Higher Learning In South Africa".

Diah, Pitaloka. 2018. Pengaruh Faktor Psikologi Wisatawan Mancanegara Terhadap Keputusan Pembelian Produk Diving Di Tanjung Benoa, Kecamatan Kuta Selatan, Kabupaten Badung Bali.

Erviana, Okky. 2013. Pengaruh Kualitas Pelayanan dan Kepercayaan Terhadap Kepuasan Pasien Rawat Inap di RSUD Dr. Soewondo Kendal.

Fandy Tjiptono. 2000. Service Quality And Satisfaction. Yogyakarta: Andi Offset . 2002. Strategi Pemasaran. Yogyakarta : Penerbit Andi . 2005. Pemasaran Jasa. Malang. Bayu Media Publishing

Fikri, Sirhan. 2016. Pengaruh Kualitas Pelayanan Terhadap Kepuasan Dan Loyalitas Mahasiswa. (Studi Pada Mahasiswa Strata 1 Fakultas Ilmu Sosial Dan Ilmu Politik Universitas Merdeka Malang).

Ghozali, Iman. 2005. Aplikasi Analisis Multivariate Dengan SPSS. Semarang:UNDIP.

Keshavarz, yousef. dan ali, m. Hareeza. (2015). The Service Quality Evaluation On Tourist Loyalty In Malaysian Hotels By The Mediating Role Of Tourist Satisfaction Dalam Mediterranean Journal Of Social Science.
Kotler dan Keller. 2009. Manajemen Pemasaran. Jilid 1. Edisi Ke 13. Jakarta:Erlangga.

Lupiyoadi, Rambat. 2001. Manajemen Pemasaran Jasa. Jakarta:PT. Salemba Empat. . 2006. Manajemen Pemasaran Jasa. Jakarta:PT. Salemba Empat.

Mouren, Margaretha. 2004. "Studi Mengenai Loyalitas Pelanggan pada Divisi Asuransi Kumpulan AJP Bumi Putra". Jurnal Sains Pemasaran Indonesia, Volume III, Nomor 3, halaman 197198.

Mukhles. 2013. Service Quality And Its Impact On Tourist Satisfiction.

Nuraini. 2009. Analisis Pengaruh Kualitas Produk, Kualitas Pelayanan, Desain Produk, Harga dan Kepercayaan terhadap Loyalitas Pelanggan. Skripsi Fakultas Ekonomi Universitas Diponegoro.

Pitana, I Gede. 2014. Pengantar Ilmu Pariwisata. Yogyakarta:Andi Offset.

Putri, Maharani. 2017. Pengaruh Kualitas Jasa Terhadap Kepercayaan dan Kepuasan Wisatawan pada Tourist Information Centre Dikota Surabaya.

Rangkuti, Freddy. 2006. Analisis SWOT. Teknik Membedah Kasus Bisnis. Jakarta:Gramedia.

Sawitri, Kertiyasa, dan Jawas Abdulla. (2013). Pengaruh Kualitas Pelayanan terhadap Kepuasan dan Loyalitas Pelangggan Tegal Sari Accomodation di Ubud.

Sihite. 2000: An Introduction On Tourism Theory.

Yoeti, Oka A. 1996. Pengantar Ilmu Pariwisata. Bandung:Angkasa.

Slovin, M. J. 1960. Sampling, Simon dan Schuster Inc. New York. 
Suwena, I Ketut dan Widyatmaja, Ngurah I Gusti. 2017. Ilmu Pariwisata. Denpasar: Udayana Universitas Press. Sugiyono, (2008).Metode penelitian kuantitatif kualitatif dan $R \& D$. Bandung: Alfabeta.

Suwantoro, Gamal. 1997. Pengantar Pariwisata. Andi:Yogyakarta.

Suwunniponth, Wanida. (2013). Tourism Satisfaction And Loyalty Toward Service Quality Of The Online Tourism Enterprises Interdiciplunary jaournal of contemporary research in business. Vol.4. No 12. April 2013.

Yudi, K. Tirta, Karini dan Dewi, L.Kusuma. (2015). Pengaruh Kualitas Pelayanan Pramuwisata Lokal terhadap Kepuasan dan Loyalitas Wisatawan di Daya Tarik Wisata Alas Kedaton Tabanan. 